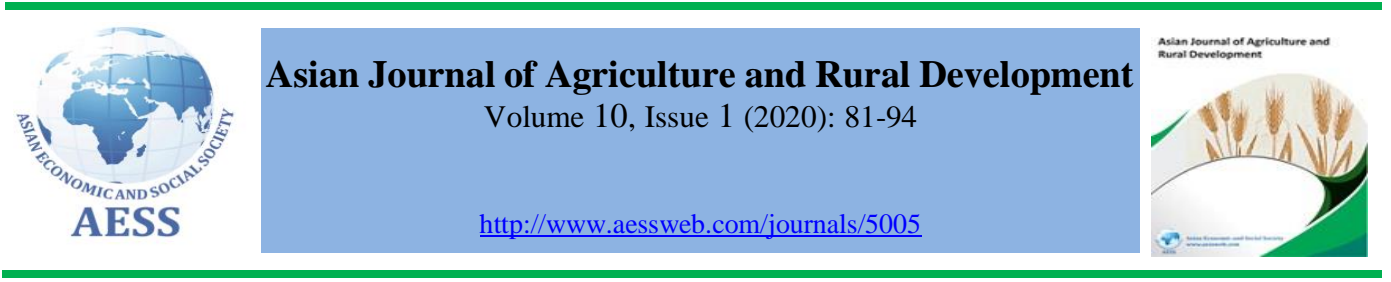

\title{
APPLICATION OF COMBINED SWOT AND AHP FOR STRATEGY DEVELOPMENT: EVIDENCE FROM POTTERY INDUSTRY OF BANGLADESH
}

\author{
Mohammad Muzahidul \\ Islam $^{\mathrm{a}}$, \\ Laizu Akter ${ }^{a}$, \\ A.K.M. Kanak Pervez ${ }^{\text {b, }}$ \\ Md. Nur Nabi ${ }^{\mathrm{c}}$ \\ Md. Momin Uddin a
a Department of Management Studies, Patuakhali Science and
Technology University, Dumki, Bangladesh
${ }^{\mathrm{b}}$ Department of Agronomy and Agricultural Extension, University of Rajshahi, Rajshahi, Bangladesh Technology University, Dumki, Bangladesh
d Department of Marketing, Patuakhali Science and Technology University, Dumki, Bangladesh \\ c Department of Finance and Banking, Patuakhali Science and
}

Zakaria Arifin d

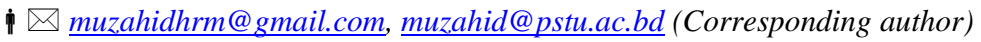

\section{ARTICLE HISTORY: \\ Received: 05-Dec-2019 \\ Accepted: 10-Feb-2020 \\ Online Available: 12-Mar- 2020}

\section{Keywords:}

Pottery,

SWOT,

AHP,

Strategy,

Bangladesh

\begin{abstract}
This study aims to explore the appropriate strategies to revive the pottery industry development in Bangladesh. The research followed SWOT-AHP combined method that is based on Analytical Hierarchy Process (AHP) weighting methodology. SWOT analysis is one of the popular tools for environmental scanning to identify the internal and external environmental factors simultaneously for defining an enterprise's strategic actions. Due to some flaws of SWOT analysis, this study followed the AHP, which is a multi-criteria decision-making approach. The qualitative data collection consisted of a Focus Group Discussion (FGD) and in-depth Interviews. We analyzed quantitative data by the AHP to identify the relative prominence of each SWOT factor analysis. The results revealed that potters have an innovative capacity. Due to the lack of administrative coordination and fierce competition with alternatives products such as plastic, metallic products, they face some difficulties. Still reliability in the marketplace is increasing with time. These findings guide to generate useful inference and could be utilized for decision-making and policies formulation in pottery industry.
\end{abstract}

Contribution/ Originality

This research significantly contributes to explore the appropriate strategies to revive the pottery industry development in Bangladesh. AHP-SWOT technique applied in the pottery sector to analysis the industry environment as well as strategy formulation, which would be a reference study to the academic researchers, MSMEs policy makers and small entrepreneurs.

DOI: 10.18488/journal.1005/2020.10.1/1005.1.81.94

ISSN (P): 2304-1455/ISSN (E):2224-4433

How to cite: Mohammad Muzahidul Islam, Laizu Akter, A.K.M. Kanak Pervez, Md. Nur Nabi, Md. Momin Uddin and Zakaria Arifin (2020). Application of combined SWOT and AHP for strategy development: evidence from pottery industry of Bangladesh. Asian Journal of Agriculture and Rural Development, 10(1), 81-94.

(C) 2020 Asian Economic and Social Society. All rights reserved. 


\section{INTRODUCTION}

As pottery is a pro-environmental, reusable and biodegradable product, its demand is increasing and getting popularity day by day to environmental concern customers, policymakers, researcher and eco-entrepreneurs. The pottery industry is one of the significant sectors in Bangladesh. MSMEs (micro, small and medium enterprises) cover about $99 \%$ of the total indusial sector in Bangladesh (World Bank, 2019). For this reason, the core economic development plan in Bangladesh is considered focusing on the MSME whereas pottery is part of it as a traditional cottage and micro- enterprises. Pottery is the alternative to the plastic, Metallic or Ceramic etc. Habitually pottery products are more frangible than the ceramic and plastic products. Pottery products like flower vase, pots, jars, sculpture, toys are very famous in the environment-conscious market as for their artistic value, degradable and environmentally friendly. Unfortunately, this sector has constantly been facing new challenges every day, being a threat to the cultural heritage as well as the economy. Market demands of pottery products are reduced because of the emergence and availability of alternative products, making it difficult for potters to perform their business. It is high time to take steps to revive the cultural heritage through strategy development to stand against the competitive field.

An organization uses SWOT analysis to analyze the strength, the weakness, the opportunities and the threats of the environment to cope with competition with the current business world. The better performance of an industry depends mostly on well interaction among the strategic factors including both the internal and external environment of an enterprise. Pottery industries are disappearing because of modernization and industrialization. Besides, competition from the organized sector also affects the business.

Maximum pottery is located Bauphal (Palpara) and Bakergong (Kalashkathi) under Barishal division (BBS, 2011). Most of the people of these areas are engaged with pottery industry as a traditional profession. They produced various products for decoration and household use. They have been contributing a lot to provide cultural and traditional products in the local community. These also have a distinct demand as an artistic object in urban markets (Khan, 2014). Pottery is currently a commercial product. Bangladeshi pottery products have demands both in the local and overseas market i.e. US, UK, New Zealand, Spain, Italy, Denmark, Australia, Japan, and France (Mimi, 2017; Islam, 2019;). Thus, government interventions to accelerate this industry and export pottery products might boost up rural entrepreneurship in this area. It is comparatively difficult for pottery industries to reach larger markets with lower production and marketing capacity.

To explore strength, utilize opportunities, minimize weaknesses and face challenges, it is significant to develop their strategy. Analytical Hierarchy Process (AHP) is a commonly used tool for mitigating the weakness of SWOT analysis (Kurttila et al., 2000). AHP is performed through qualitative and quantitative analysis to make a decision among complex alternatives and prioritize them by the pair comparison matrix by using Saaty's scale. This prioritization helps to make strategic development of pottery in Bangladesh. There are many previous types of research comprising the application of AHP in disciplines such as agriculture, tourism, forest planning, social science, women education. However, there is few, relevant research on the application of AHP in the SME sector (Ahmad and Pirzada, 2014) especially in the pottery industry. The business, which is mainly based on the family tradition, needs an entrepreneurial approach in its development and finding new markets to compete with the substitute product as an organized sector. The objective of this study is to apprehend the best strategy to develop pottery business management through SWOT (Strength, Weaknesses, Opportunities, and Threats) analysis, and AHP is used in the amalgamation. 


\section{LITERATURE REVIEW}

Nowadays most organizations involved in strategic planning. Strategic planning is a way to boost an organization to be more productive by allocating resources in a structured approach to achieve goals (David, 2003). Successful strategic management depends on strategic planning. Strategic planning consists of analysis (organization, person \& task), decisions, and deeds an organization endeavours to develop and adapt to competitive advantages.

It commences with vision (Figure 1). Concept shows the picture of the desired future position of the organization. The next step in the strategic management process begins with a mission. An organization's mission is its time-consuming purpose which defines both what an organization years after the desired period and what it wants to eliminate to catch the mission. The third step of the strategic management process includes objectives. An organization aspires to reach its concrete goals by setting objectives. The next phase of the strategic management process is environmental scanning which includes the external and internal analysis, also called SWOT Analysis. SWOT is a tool of situational assessment applied by strategic planners of the project or business organization to evaluate the current status to choose the best alternatives for the future direction (Zavadskas et al., 2011). It aims to identify the key internal and external factors seen as essential to achieving the goal (figure 2 and 3). SWOT gathers and organizes information (see figure 4) concerning the internal and external environment of an organization facing the immediate and near future (Osuna and Aranda, 2007).

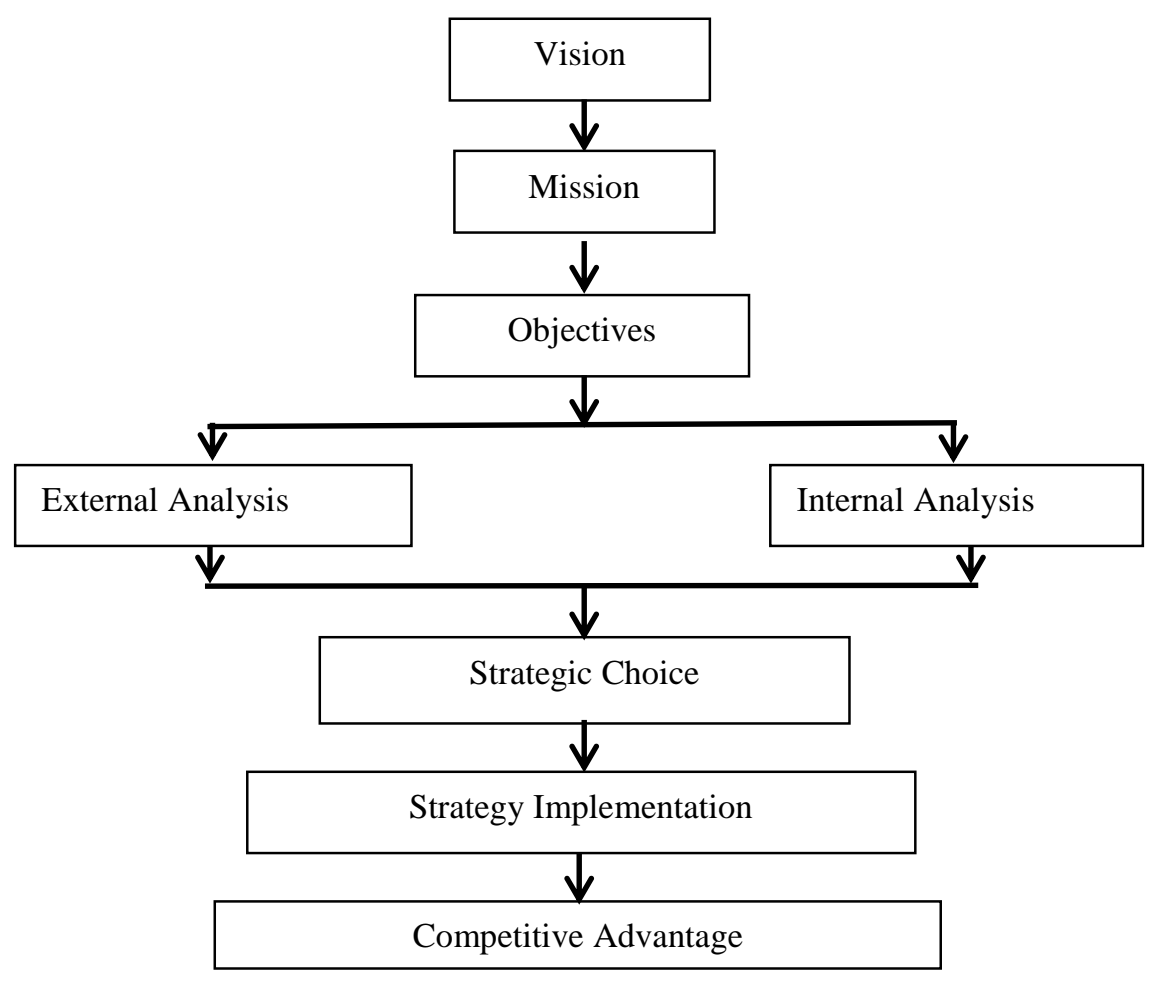

\section{Figure 1: Strategic management process}

The following figures show internal and external environmental dimensions of environmental analysis at a glance for exploring strategic options. 


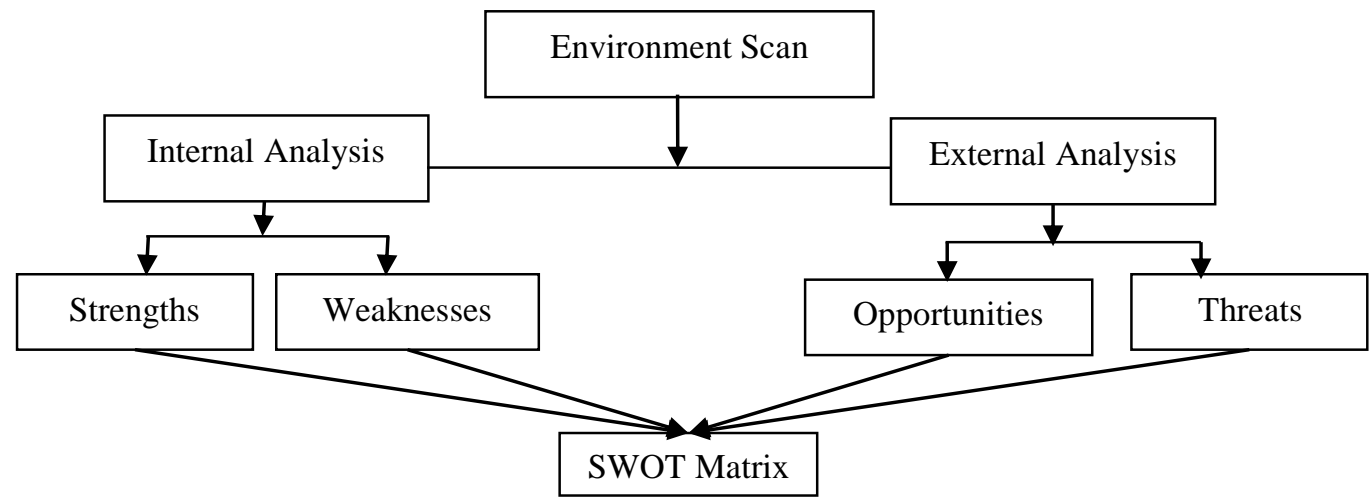

Figure 2: Strength, weaknesses, opportunities and threats matrix

In addition, another model of SWOT analysis is Threats, Opportunities, Weaknesses, and Strengths (TOWS) Strategic Alternative Matrix (see below table)

\begin{tabular}{lll}
\hline & Internal Strengths (S) & Internal Weaknesses (W) \\
\hline \multirow{2}{*}{ External } & SO: "Maxi-Maxi" Strategy & WO: "Mini-Maxi” Strategy \\
Opportunities (O) & Strategies that use strengths to & Strategies that minimize weakness by \\
& maximize opportunities & taking advantage of opportunities \\
& ST: "Maxi-Mini" Strategy & WT: "Mini-mini" Strategy \\
External Threats (T) & $\begin{array}{l}\text { Strategies that use strengths to } \\
\text { minimize threats }\end{array}$ & $\begin{array}{l}\text { Strategies that minimize weakness } \\
\text { and avoid threats }\end{array}$ \\
\hline
\end{tabular}

Source: Weihrich (1982)

The AHP is a tool for complex decision making to help the decision-makers to set priorities effectively and make the best decision among the sophisticated alternatives. Thomas Saaty introduced it in 1980 (Saaty, 1994). Moreover, it is a useful technique to check the consistency of the decision maker's appraisement which reduces the bias in the decision-making process in a perplex situation (Al-Harbi, 2001). AHP accomplishes pair-wise resemblance to find out the relative importance of the variable in each hierarchy level to make the best decision among substitutes (Saaty,1990). Thomas Saaty developed a comparison scale to perform the prioritization mechanism in 1980 to represent the relative importance of the criteria. The value of pair comparison matrices of these factors is used to provide the means for decision making evaluations (Triantaphyllou and Mann, 1995). It has wide application in many areas like economic (CervellóRoyo et al., 2015), social (Westhues et al., 2001), and management science (Ansary et al., 2009).

AHP moulds decision-making problem and exhorts the decision-making process by identifying objectives, criteria, and alternatives, by comparing criteria and alternatives between pairs and defining priorities of alternatives (Oreski, 2012). The AHP includes both qualitative and quantitative decision attributes proportionately, and its pliancy concerning the setting of objectives (Kurttila et al., 2000).

Moreover, AHP and SWOT are the most well-known tool to analysis the environmental factors for exploring strategies formulation in the SMEs sector. It is also one of the best techniques to policy makers and researchers to the appropriate strategy development of informal and unstructured sector (Khatri and Metri, 2016). In Bangladesh, pottery industry comprises under MSMEs category. In this context, AHP-SWOT technique applied in the pottery sector to analysis the industry environment as well as strategy formulation. 


\section{COMBINED AHP-SWOT METHODOLOGY}

The limitations of SWOT analysis to prioritize for future strategy can be overcome by using combined AHP-SWOT. It was first proposed by Kurttila (Yavuz and Baycan, 2013). The AHP is a commonly used decision-making tool to perform the pair-wise comparison and prioritized them using Eigen value analysis (Triantaphyllou and Mann, 1995).

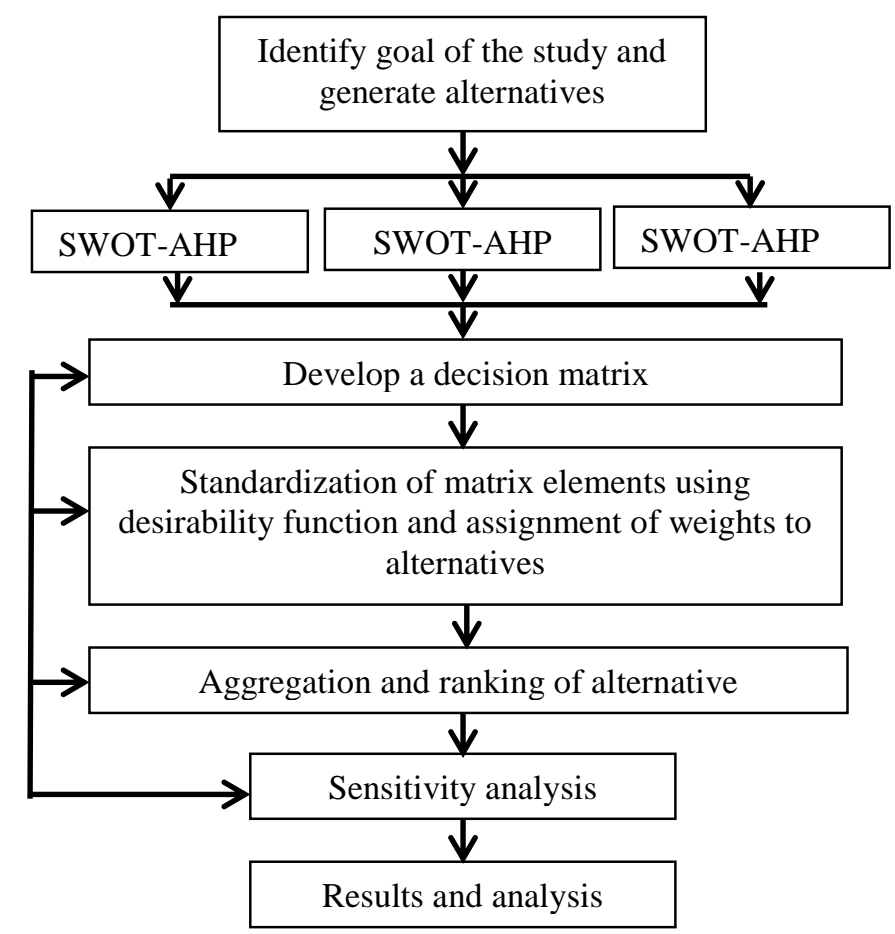

Figure 3: Combined analytic hierarchy process strengths, weaknesses, opportunities and threats analysis

The combined AHP-SWOT has wide applications in various sectors. Like milk sector (Erdil and Erbiyık, 2015), manufacturing firm (Görener et al., 2012), tourism sector (Jeon and Kim, 2011) (Görener et al., 2012), forest certification (Kurttila et al., 2000), management (Subramanian and Ramanathan, 2012), marketing plan (Nganga and Maruyama, 2015), education (Lee et al., 2013), agriculture (Wota and Wozniak, 2015).

Some researchers elaborated SWOT-AHP by adjoining it with a fuzzy analytic hierarchy process which is called fuzzy AHP-SWOT or multiple criteria group decision-making (MCGDM) (Yavuz and Baycan, 2014). The fuzzy AHP-SWOT provides fuzzy judgment in pair-wise comparisons in lieu of strict judgment with the aim of reflecting a style of human thinking in real-world decisionmaking problems (Kahraman et al., 2004). They performed combined AHP-SWOT analysis by scanning the external and internal environment of an organization. In order to determine the relative importance of SWOT factors, then the AHP performs pair-wise comparisons among factors (Chang and Huang, 2006). To ascertain the weight of each SWOT group, the pair-wise comparison is performed. In the third step, the Analytical Hierarchy Process is applied. Finally, they attained the overall factor rank by multiplying the factor's local weight with the specific group weight (Ramadhan et al., 1999). AHP is also useful if many interests are involved and a number of people participate in the decision-making process. AHP is a straightforward and transparent method that is 
also able to consider subjective and judgmental information (Salo et al., 2003). AHP can deal with qualitative as well as quantitative attributes (Kamal and Alsudairi, 2009).

The combined AHP- SWOT is performed through four steps-

i. The foremost step is to environmental scanning to identify the internal and external issues for strategic planning and creating the hierarchy of criteria and sub-criteria

Goal

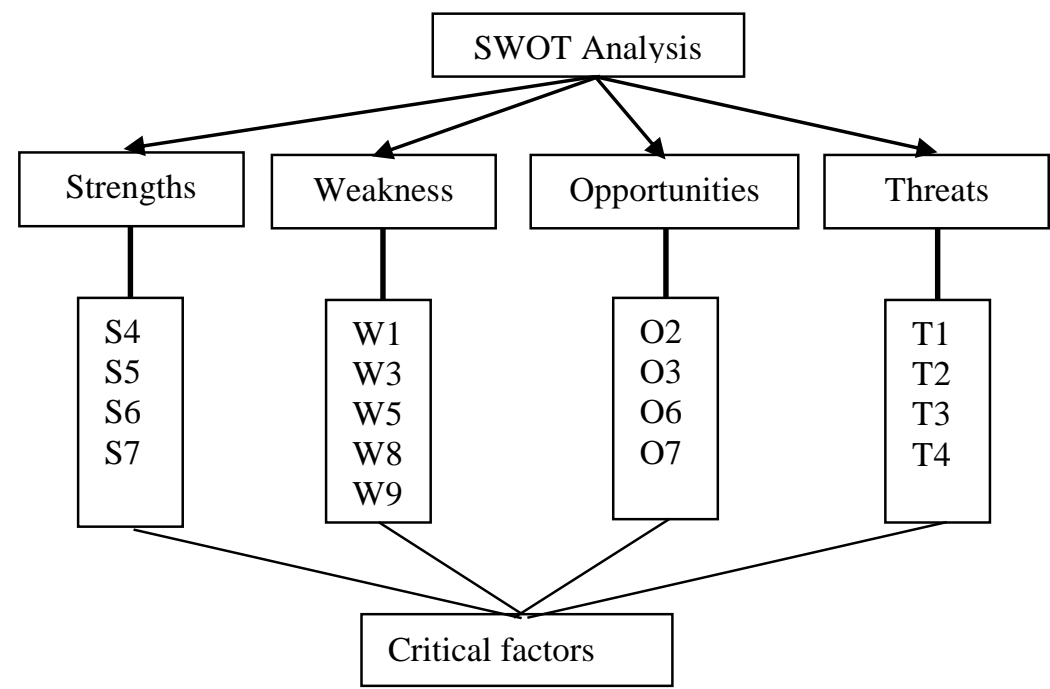

Figure 4: SWOT sub factors through AHP to reach critical factors

ii. The second step is to make pair-wise comparisons between the factors to capture the weights according to Saaty's scale (1980).

\begin{tabular}{lccc}
\hline & A1 & A2 & $\ldots \ldots$ An \\
\hline A1 & 1 & $x$ & $\ldots \ldots \ldots \mathrm{y}$ \\
$\mathrm{A} 2$ & $1 / \mathrm{x}$ & 1 & $\ldots \ldots \ldots \mathrm{z}$ \\
$\mathrm{A}_{\mathrm{n}}$ & $1 / \mathrm{y}$ & $1 \mathrm{lz}$ & $\ldots \ldots \ldots 1$ \\
\hline
\end{tabular}

Pair-wise comparison

\begin{tabular}{ll}
\hline Intensity of Importance & \multicolumn{1}{c}{ Definition } \\
\hline 1 & Equally important \\
3 & Moderately more important \\
5 & Much more important \\
7 & Immensely more important \\
9 & Entirely more important \\
$2,4,6,8$ & Interior values \\
\hline
\end{tabular}

\section{Source: Saaty (1980)}

iii. In the third step, normalization of each matrix is used to find the relative weights. The relative weights are given by the right eigenvector (Lambda max), as:

$$
\text { Aw }=\text { Lambda-max } \times \text { relative weights }
$$

iv. The final step is to check the consistency level. The calculation of the Consistency Index (CI): 


$$
C I=(\operatorname{Lambda} \max -n) /(n-1)
$$

We obtained the Random Index (RI) is obtained by Saaty and Forman's scale (1993)

\begin{tabular}{cccccccccc}
\hline $\mathrm{N}$ & 2 & 3 & 4 & 5 & 6 & 7 & 8 & 9 & 10 \\
$\mathrm{RI}$ & 0 & 0.58 & 0.90 & 1.12 & 1.24 & 1.32 & 1.41 & 1.45 & 1.51 \\
\hline
\end{tabular}

Source: Saaty and Forman (1993)

Consistency Ratio $(\mathrm{CR})=$ Consistency Index $(\mathrm{CI}) /$ Random Index $(\mathrm{RI})$

If $\mathrm{CR}<10 \%$, then the decision maker pair-wise comparisons are relatively consistent. If $\mathrm{CR}>$ $10 \%$, then inconsistency exists in decision maker evaluations.

At the last stage, the overall priority vector is calculated by multiplying the factor's local weights by the specific group weight to find out the priority ranking of SWOT factors.

\section{CONCEPTUAL FRAMEWORK}

The following conceptual framework has been illustrated after rigorous literature review which will lead to exploring strategic options for the pottery industry development.

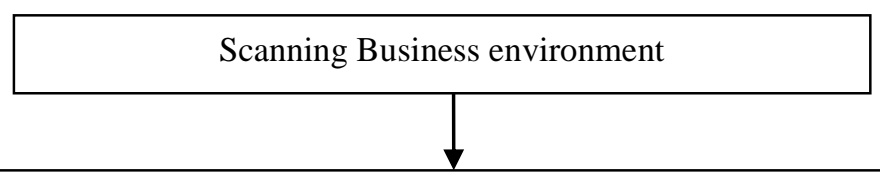

Identification of considerable strengths, weakness, opportunities, and threats

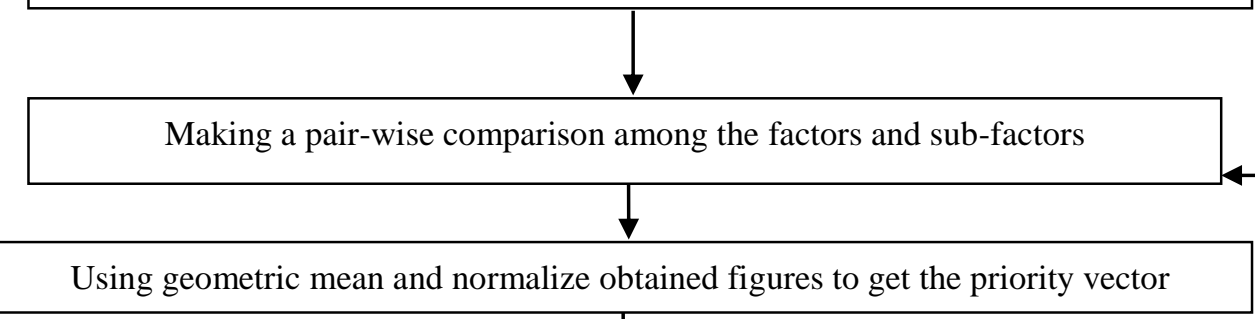

Using geometric mean and normalize obtained figures to get the priority vector

\begin{tabular}{|c|c|c|}
\hline \multicolumn{3}{|c|}{ Calculation of the consistency ratio (CR) of SWOT criteria and sub-criteria } \\
\hline $\begin{array}{c}\text { Calculation of consistency } \\
\text { index }(\mathrm{CI})=(\text { Lambda max-n/n-1) }\end{array}$ & $\begin{array}{l}\text { Determination of Random index (RI) } \\
\text { according to the matrix by using } \\
\text { Foreman and Saaty's scale }\end{array}$ & $\begin{array}{l}\text { Calculation of consiste } \\
\text { ratio }(\mathrm{CR})=\mathrm{CI} / \mathrm{RI}\end{array}$ \\
\hline If $\mathrm{CR}<0.01$ & \multicolumn{2}{|c|}{ If $\mathrm{CR}>0.01$} \\
\hline \multicolumn{3}{|c|}{$\begin{array}{l}\text { Determine the degree of the global importance of the SWOT sub-factors, multiplying } \\
\text { factor's weights by the local sub-factor's priority vectors }\end{array}$} \\
\hline \multicolumn{3}{|c|}{$\downarrow$} \\
\hline \multicolumn{3}{|c|}{ Creating a hierarchy of the SWOT factors, and defining the most important strategy } \\
\hline
\end{tabular}




\section{COMBINED AHP-SWOT IN POTTERY INDUSTRY}

Selecting appropriate strategies is very important for the pottery industry in the Barishal Division. Here SWOT analysis in combination with AHP is utilized for the selection of the best strategy for the pottery industry in the Barishal Division. Pre-survey, In-depth Interviews and four Focus group discussions were performed to identify the internal (Strengths, Weakness) environment and the external (Opportunities, Threats) environment of Palpara (Bauphal) of Patuakhali district and Kalaskathi (Bakergong) of Barishal district under Barishal Division in Bangladesh during JanuaryApril, 2019. In this study, firstly strength, weaknesses, opportunities, and threats of the pottery industry in the Barishal Division were identified and then pair-wise comparisons were determined. In this way, we identified five strength, five weaknesses, four opportunities, and four threats.

Table 1: SWOT Matrix of the pottery

\begin{tabular}{llll}
\hline Strength & \multicolumn{1}{c}{ Weakness } & \multicolumn{1}{c}{ Opportunities } & \multicolumn{1}{c}{ Threats } \\
\hline $\begin{array}{l}\text { S1 = Availability of } \\
\text { resource }\end{array}$ & W1 = Insufficient & O1 = Increasing & T1 = Competition \\
S2 = Availability of & Technology & international reputation & T2= Changing \\
skilled craftsman & coordination with the & as eco-product & Onternational market \\
S3 = Innovative & local administration & reliability in the & T3 = Negative \\
capacity & W3 = Inadequate & marketplace & safety and security \\
S4 = Quality of the & Marketing Promotion & O3 = Increasing & T4 = Modernization of \\
product & W4= Lack of the & government & alternative industry \\
S5= Good Benefit- & facility to work in the & intervention & \\
Cost Ratio (BCR) & rainy season & O4 = Increasing & \\
comparatively & W5 = Inadequate & demand for household & \\
& training facilities & and interior & \\
& & & \\
& & &
\end{tabular}

Source: Field Survey, 2019

\section{DATA ANALYSIS}

In this study, we made the pair-wise comparison of the SWOT groups using Saaty's (1980) scale. The value of comparison tables is shown in the appendix. We performed Focus Group Discussions (FGD) to make all pair-wise comparisons of this analysis. We entered data obtained from Focus Group Discussion in excel to prioritized using the Multiple Attribute Decision Making (MADM) approach (AHP method).

\section{RESULTS AND DISCUSSIONS}

In this study, significant strategic forces were ascertained in the pottery industry in the combined SWOT-AHP method. The SWOT group priority rank: Strengths-44.25\%, Weakness-16\%, Opportunities-30\%, and Challenge-9\%. According to this analysis, the most significant factor in the SWOT group is competition from threat groups. The overall priority vector is 1.98 . In Kalaskathi and Bauphal, most of the family members are leaving countries because of their failure to cope with the competition. In the case of the manufacturing firm (Görener et al., 2012) combined AHP-SWOT also showed that the most significant factors were rising of living standards and modern equipment from the opportunity's group. In Strength's group, the most important factor is the innovative capacity (0.34) of the potter, and artisans. They have innovative capacity but due to some constraints, this is also going in vain. Most of the potters said, they are finding it difficult to afford the cost of clay, coal, labor and other materials. Maximum potters have no modern equipment. In Bauphal, only a few families have some modern machinery. However, in 
Kalaskathi, nobody has any kind of modern equipment. Because of these constraints, they cannot apply their innovative capacity in the production process.

In the weakness group, poor coordination in administration (0.26) is considerable. In Kalaskathi, potters said that the government does not provide any supportive facility to carry out their profession. At the time of shipping their products, they face some problems. In Bauphal, at the time of clay collection, local police deter them from collecting clay. They have a negative perception of safety and security about the canal. However, according to the potter of Bauphal Upazilla, there is no risk to the environment.

In the opportunity's group, the most significant factor is improving reliability in the marketplace (0.29). Potters are working their best to enhance reliability in the national and foreign market. Based on this intimation potter must adopt substitute plans and select the most desirable strategy according to its demands. The concern authority should restructure the pottery industry i.e. its mission, vision and goal to cope with competition and save them from disappearing.

\section{CONCLUSION}

Pottery is one of the primitive sectors in Bangladesh. Poor and unemployed people are becoming self-dependent (Survive driven) through pottery activities in rural Bangladesh. Potters of the study areas have the innovative capacity, expert artisan but are bound with a lot of difficulties. They are suffering from insufficient technology, modern equipment, and inadequate training facilities. Competition from structured organizations hinders them from making a profit. Besides, many pottery families are disappearing because of substitute products occupy the market. Integrated SWOT-AHP brought up a structured way and analytical means for pottery resurrection strategic planning. Despite many constraints, reliability in the marketplace is increasing day by day because of the pro-environmental and quality products in the industry. The use of AHP-SWOT has assisted in realizing the idiosyncrasies of pottery industry qualitatively and quantitatively. Finally, to revive this sector, the government and private organizations are needed to follow policies guidelines of this research in decision making and policies formulation for the pottery industry development.

\subsection{Policy Implications}

From the analysis, some policy implications for overcoming the constraints of the pottery industry have been pointed out below-

- Many potters of the study areas are leaving their profession because of inconsistency in their supply-demand coordination and new generations are reluctant to develop their career as a potter. The entrepreneurial opportunities of this industry need to explore and let to know the members of potters families. Notably, they face difficulties at the time of collecting clay from the canal. The local administration restricts them because of their anxious about the safety and security of the environment. Thus, the local administration should inform them about the appropriate sources and collecting approach of the clay.

- Many potters suffer from working capital. Due to working capital, they cannot expand their business. The government organization such as BSCIC should provide a special financial assistance for the pottery sector like as the agriculture sector.

- Many potters said that they do not have a training facility in locally. Sometimes it becomes difficult, especially for women to get need-based training from remote places. The concern government organization should arrange regular training programs in the Barishal Division to train them to make world-class products. Besides, BSCIC, BARD, SME Foundation Bangladesh, PKSF and other government and non-government organizations (NGOs) such as Banglacraft, Aarong, Caritas, Heed Bangladesh should provide training facilities to enhance their innovativeness and capability to add value to their existing products or to design new products. 
- Potters of the study areas said that they do not find any special loan facility. The Bank, NGO, and other financial institutions should provide loan support with a small interest rate. This will help them continue and expand their business.

- Most of the potters use traditional equipment to produce pottery. It is costly and timeconsuming. Most of the potters should use modern equipment to increase production rates and improve product quality.

- The ICT division should provide support such as training on e-business, e-marketing to operate their business in the digital market. It would be an effective approach for entrepreneurs to receive and delivery of the order from the rural area.

- Export promotion bureau (EPB), SME Foundation, and local administration should organize product exhibition or trade fair at home and abroad. Besides, they can also organize awareness programs highlighting the bad effects of plastics products on environment and motivate people to purchase environmental friendly products such as diversified pottery products.

Funding: The study received financial support from the Research and Training Centre (RTC), Patuakhali Science and Technology University, Bangladesh.

Competing Interests: The authors have no conflicts of interest regarding the publication of this research paper.

Contributors/Acknowledgement: The authors contributed equally in the current study.

Views and opinions expressed in this study are the views and opinions of the authors, Asian Journal of Agriculture and Rural Development shall not be responsible or answerable for any loss, damage or liability etc. caused in relation to/arising out of the use of the content.

\section{References}

Ahmad, Y., \& Pirzada, D. S. (2014). Using analytic hierarchy process for exploring prioritization of functional strategies in auto parts manufacturing SMEs of Pakistan. Journal of Business and Management Research, 2(3), 1-12. doi.org/10.1177/2158244014553560.

Al-Harbi, K. M. A. S. (2001). Application of the AHP in project management. International Journal of Project Management, 19(1), 19-27. doi.org/10.5267/j.jpm.2018.1.001.

Ansary, M., Rahimi, A. R., Yarmohamadian, M. H., \& Yaghobbi, M. (2009). SWOT Analysis in school of management and medical information science. Journal of Health Administration, 12(36), 33-38.

BBS (2011). District Statistics (Patuakhali \& Barishal), Bangladesh bureau of statistics, ministry of planning government of the people's republic of Bangladesh. Available at www.bbs.gov.bd.

Cervelló-Royo, R., Guijarro, F., Pfahler, T., \& Marion, P. (2015). An analytic hierarchy process (AHP) framework for property valuation to identify the ideal 2050 portfolio mixes in EU27 countries with shrinking populations. Quality \& Quantity, 50, 2313-2329. doi.org/10.1007/s11135-015-0264-3

Chang, H. H., \& Huang, W. C. (2006). Application of a quantification SWOT analytical method. Mathematical and Computer Modelling, 43(1-2), 158-169.

David, F. R. (2003). Strategic Management-Concepts and Cases, (9th Edition), USA: Pearson Education. 32-49.

Erdil, A., \& Erbıyık, E. (2015) Selection strategy via analytic hierarchy process: an application for a small enterprise in milk sector. Procedia - Social and Behavioral Sciences, 195, 2618 2628. doi.org/10.1016/j.sbspro.2015.06.463.

Görener, A., Toker, K., \& Ulucay, K. (2012). Application of combined SWOT and AHP: a case study for a manufacturing firm. Procedia-social and behavioral sciences 58: 1525-1534. Cited on 31 October 2019. A vailable at: file:///C:/Users/Hp/Downloads/Application_of_Combined_SWOT_and_AHP_A_Case_Stud Y_.pdf. 
Islam, K. Z. (2019). Shariatpur pottery items are exported worldwide but the potters are not getting their fair share, Dhaka Tribune, Retrieved from https://www.dhakatribune.com/business/2019/01/21/shariatpur-pottery-items-are-exportedworldwide-but-the-potters-are-not-getting-their-fair-share.

Jeon, Y. A., \& Kim, J. (2011). An application of SWOT-AHP to develop a strategic planning for a tourist destination, Proceedings of 16th Graduate Students Research Conference, Texas, 2011.

Kahraman, C., Cebeci, U., \& Ruan, D. (2004). Multi-attribute comparison of catering service companies using fuzzy AHP: The case of Turkey. International Journal of Production Economics, 87(2), 171-184. doi.org/10.1016/s0925-5273(03)00099-9.

Kamal, M. M., \& Alsudairi, M. (2009). Investigating the importance of factors influencing integration technology adoption in local government authorities. Transforming Government: People, Process and Policy, 3(3), 302-331.

Khan, S. (2014). Bangladesh lokojo songskriti gronthsmala: (Patuakhali and Barishal), Bangla Academy, Dhaka 1000, Bangladesh.

Khatri, J. K., \& Metri, B. (2016). SWOT-AHP approach for sustainable manufacturing strategy selection: a case of Indian SME. Global Business Review, 17(5), 1-16.

Kurttila, M., Pesonena, M., Kangasb, J., \& Kajanusa, M. (2000). Utilizing the analytic hierarchy process (AHP) in SWOT analysis-a hybrid method and its application to a forestcertification case. Forest Policy and Economics, 1(1), 41-52.

Lee, C., Hwa, H. S., \& Chang, J. (2013). Factors influencing sociability in educational MMORPGs - a fuzzy AHP approach. Internet Research, 23(3), 298-315.

Mimi, N. Z. (2017). The story of clay pottery, lifestyle, decor, The Daily Star, Retrived from https://www.thedailystar.net/lifestyle/decor/the-story-clay-pottery-1389253.

Nganga, P. S., \& Maruyama, Y. (2015). Market Attractiveness evaluation of Sub-Saharan Africa. Applying SWOT analysis and AHP methods. Journal of Economics and Economic Education Research, 16(1), 1-18

Oreski, D. (2012). Strategy development by using SWOT-AHP. Tem Journal, 1(4), 283-291.

Osuna, E. E., \& Aranda, A. (2007). Combining SWOT and AHP techniques for strategic planning. Proceedings of the 9th International Symposium on the Analytic Hierarchy Process for Multi-criteria Decision Making, August 2-6, 2007. Viña del Mar, Chile. Retrived from http://www.isahp.org/2007Proceedings/Papers/Working\%20Sessions/Development\%20Plan ning/Combining\%20SWOT\%20and\%20AHP.pdf.

Ramadhan, R. H., Al-Abdul, Wahhab, H. I., \& Duffuaa, O. S. (1999). The use of an analytical hierarchy process in pavement maintenance priority ranking. Journal of Quality in Maintenance Engineering, 5(1), 25-39.

Saaty, T. L. (1980). The Analytic Hierarchy Process, New York: McGraw Hill, USA.

Saaty, T. L. (1990). How to make a decision: the analytic hierarchy process. European Journal of Operational Research, 48(1), 9-26.

Saaty, T. L. (1994). How to make a decision: the analytic hierarchy process. Interfaces, 24(6), 1943.

Saaty, T. L., \& Forman, E. H. (1993). The Hierarchon - A Dictionary of Hierarchies. Pittsburgh, PA: RWS Publications

Salo, A., Gustafsson, T., \& Ramanathan, R. (2003). Multicriteria methods for technology foresight. Journal of Forecasting, 22, 235-255.

Subramanian, N., \& Ramanathan, R. (2012). A review of applications of analytic hierarchy process in operations management. International Journal of Production Economics, 138(2), 215241.

Triantaphyllou, E., \& Mann, S. H. (1995). Using the analytic hierarchy process for decision making in engineering applications: some challenges. International Journal of Industrial Engineering: Applications and Practice, 2(1), 35-44.

Weihrich, H. (1982). The TOWS matrix-A tool for situational analysis. Long Range Plan, 15(2), 54-66. 
Westhues, A., Jean, L. J., \& Schmidt, G. (2001). A SWOT analysis of social work education in Canada. Journal Social Work Education, 20(1), 35-56. doi.org/10.1080/02615470020028364.

World Bank (2019). Financing Solutions for Micro, Small and Medium Enterprises in Bangladesh, Policy Research Institute, The World Bank Group, Washington, DC, USA.

Wota, A. K., \& Woźniak, A. (2015). The application of the SWOT and AHP methods for the assessment of regions strategic position in the aspect of wind energy. Agricultural Engineering, 19(4), 129-138.

Yavuz, F., \& Baycan, T. (2013). Use of swot and analytic hierarchy process integration as a participatory decision making tool in watershed management. Procedia Technol, 8, 134-143.

Yavuz, F., \& Baycan, T. (2014). Application of combined Analytic Hierarchy Process (AHP) and SWOT for integrated watershed management. International Journal of the Analytical Hierarchy Process, 6(1), 3-32.

Zavadskas, E. K, Turskisj, Z., \& Tamosaitiene, J. (2011). Selection of construction enterprises management strategy based on the SWOT and multi-criteria analysis. Archives of Civil and Mechanical Engineering, 11(4), 1063-1082.

\section{Appendix}

Table 2: The pair-wise comparison of strengths, weaknesses, opportunities and threats (SWOT) groups

\begin{tabular}{lcccc}
\hline & S & W & O & T \\
\hline S & 1 & 2.71 & 1.86 & 4.36 \\
W & 0.37 & 1 & 0.34 & 2.45 \\
O & 0.54 & 2.94 & 1 & 2.63 \\
T & 0.23 & 0.4 & 0.38 & 1 \\
SUM & 2.14 & 7.05 & 3.58 & 10.44 \\
\hline
\end{tabular}

Source: Field Survey, 2019

Table 3: Normalized value of SWOT factors

\begin{tabular}{cccccc}
\hline & S & W & O & T & PV \\
\hline $\mathrm{S}$ & 0.46 & 0.38 & 0.51 & 0.42 & 0.4425 \\
$\mathrm{~W}$ & 0.17 & 0.14 & 0.09 & 0.24 & 0.16 \\
$\mathrm{O}$ & 0.25 & 0.42 & 0.28 & 0.25 & 0.3 \\
$\mathrm{~T}$ & 0.1 & 0.06 & 0.1 & 0.1 & 0.09 \\
\hline
\end{tabular}

Source: Field Survey, 2019

Table 4: Priority vector of SWOT factors

\begin{tabular}{lccccc}
\hline & S & W & O & T & PV \\
\hline S & 1 & 2.71 & 1.86 & 4.36 & 0.4425 \\
W & 0.37 & 1 & 0.34 & 2.45 & 0.16 \\
O & 0.54 & 2.94 & 1 & 2.63 & 0.3 \\
T & 0.23 & 0.4 & 0.38 & 1 & 0.09 \\
SUM & 2.14 & 7.05 & 3.58 & 10.44 & \\
SUM*PV & 0.94 & 1.13 & 1.07 & 0.94 & \\
Lambda Max & 4.08 & & & & \\
CR & 0.03 & & & & \\
\hline
\end{tabular}

Source: Field Survey, 2019 
Table 5: Pair-wise comparison of the SWOT sub criteria- strength

\begin{tabular}{lcccccc}
\hline & S1 & S2 & S3 & S4 & S5 & PV \\
\hline S1 & 1 & 1.57 & 2.06 & 3.66 & 2.91 & 0.34 \\
S2 & 0.64 & 1 & 2.21 & 3.31 & 2.06 & 0.27 \\
S3 & 0.49 & 0.45 & 1 & 1.57 & 3.31 & 0.176 \\
S4 & 0.27 & 0.3 & 0.64 & 1 & 3.66 & 0.132 \\
S5 & 0.34 & 0.49 & 0.3 & 0.27 & 1 & 0.08 \\
SUM & 2.74 & 3.81 & 6.21 & 9.81 & 12.94 & \\
SUM*PV & 0.93 & 1.03 & 1.09 & 1.29 & 1.04 & \\
Lambda max & 5.38 & & & & & \\
CR & 0.08 & & & & & \\
\hline
\end{tabular}

Source: Field Survey, 2019

Table 6: Pair-wise comparisons of the SWOT sub criteria- weakness

\begin{tabular}{lcccccc}
\hline & W1 & W2 & W3 & W4 & W5 & PV \\
\hline W1 & 1 & 1.32 & 1.57 & 0.84 & 1.11 & 0.23 \\
W2 & 0.76 & 1 & 2.06 & 2.06 & 1.32 & 0.26 \\
W3 & 0.64 & 0.49 & 1 & 1.32 & 0.76 & 0.15 \\
W4 & 1.19 & 0.49 & 0.76 & 1 & 0.64 & 0.16 \\
W5 & 0.90 & 0.76 & 1.32 & 1.56 & 1 & 0.20 \\
SUM & 4.49 & 4.05 & 6.71 & 6.78 & 4.82 & 1.00 \\
SUM*PV & 1.02 & 1.05 & 1.02 & 1.06 & 0.99 & \\
Lambda-max & 5.14 & & & & & \\
CR & 0.03 & & & & & \\
\hline
\end{tabular}

Source: Field Survey, 2019

Table 7: Pair-wise comparisons of the SWOT sub criteria- opportunity

\begin{tabular}{lccccc}
\hline & O1 & O2 & O3 & O4 & PV \\
\hline O1 & 1.00 & 0.90 & 1.46 & 0.76 & 0.25 \\
O2 & 1.11 & 1.00 & 1.11 & 1.86 & 0.29 \\
O3 & 0.69 & 0.90 & 1.00 & 2.59 & 0.28 \\
O4 & 1.32 & 0.54 & 0.39 & 1.00 & 0.18 \\
SUM & 4.11 & 3.34 & 3.95 & 6.21 & \\
SUM*PV & 1.03 & 0.96 & 1.09 & 1.15 & \\
Lambda- max & 4.23 & & & & \\
CR & 0.09 & & & & \\
\hline
\end{tabular}

Source: Field Survey, 2019

Table 8: Pair-wise comparison of the SWOT sub criteria- threat

\begin{tabular}{lccccc}
\hline & T1 & T2 & T3 & T4 & PV \\
\hline T1 & 1.00 & 3.66 & 2.06 & 1.19 & 1.98 \\
T2 & 0.27 & 1.00 & 0.97 & 0.71 & 0.74 \\
T3 & 0.49 & 1.03 & 1.00 & 1.97 & 1.12 \\
T4 & 0.84 & 1.41 & 0.51 & 1.00 & 0.94 \\
Sum & 2.60 & 7.10 & 4.54 & 4.86 & \\
Sum *PV & 1.04 & 1.08 & 1.09 & 1.02 & \\
Lambda- max & 4.22 & & & & \\
CR & 0.08 & & & & \\
\hline
\end{tabular}

Source: Field Survey, 2019 
Table 9: Overall priority scores strengths, weaknesses, opportunities and threats (SWOT) analysis

\begin{tabular}{|c|c|c|c|c|c|}
\hline SWOT & $\begin{array}{l}\text { Group- } \\
\text { wise } \\
\text { Priority }\end{array}$ & Factors & $\begin{array}{l}\text { Priority } \\
\text { vector } \\
\text { within the } \\
\text { group }\end{array}$ & $\begin{array}{c}\text { The } \\
\text { overall } \\
\text { priority } \\
\text { vector }\end{array}$ & Rank \\
\hline \multirow{5}{*}{ Strengths } & \multirow{5}{*}{0.4425} & Innovative capacity & 0.34 & 0.15 & 1 \\
\hline & & Availability of expert artisans & 0.27 & 0.11 & 2 \\
\hline & & Resources and skills availability & 0.176 & 0.08 & 3 \\
\hline & & Product quality & 0.132 & 0.05 & 4 \\
\hline & & Good Benefit-Cost Ratio (BCR) & .08 & .04 & 5 \\
\hline \multirow{5}{*}{ Weakness } & \multirow{5}{*}{0.16} & Insufficient Technology & 0.23 & 0.037 & 2 \\
\hline & & $\begin{array}{l}\text { Poor coordination in } \\
\text { administration }\end{array}$ & 0.26 & 0.041 & 1 \\
\hline & & Inadequate Marketing Promotion & 0.15 & 0.024 & 5 \\
\hline & & $\begin{array}{l}\text { Lack of shed facility to work in } \\
\text { the rainy season }\end{array}$ & 0.16 & 0.026 & 4 \\
\hline & & Inadequate training facilities & 0.20 & 0.032 & 3 \\
\hline \multirow{4}{*}{ Opportunities } & \multirow{4}{*}{0.3} & Increasing international reputation & 0.25 & 0.075 & 3 \\
\hline & & $\begin{array}{l}\text { Increasing reliability in } \\
\text { marketplace }\end{array}$ & 0.29 & 0.087 & 1 \\
\hline & & $\begin{array}{l}\text { Increasing government } \\
\text { intervention }\end{array}$ & 0.28 & 0.084 & 2 \\
\hline & & $\begin{array}{l}\text { Increasing demand for household } \\
\text { and interior decoration's usage }\end{array}$ & 0.18 & 0.054 & 4 \\
\hline \multirow{4}{*}{ Threats } & \multirow{4}{*}{0.09} & Competition & 1.98 & 0.18 & 1 \\
\hline & & Changing international market & 0.74 & 0.067 & 4 \\
\hline & & $\begin{array}{l}\text { Negative perception regarding } \\
\text { safety and security }\end{array}$ & 1.12 & 0.10 & 2 \\
\hline & & Modernization & 0.94 & 0.08 & 3 \\
\hline
\end{tabular}

Source: Field Survey, 2019 